\title{
鳥取沿岸の侵食実態と総合的な土砂管理の検討 一千代川右岸流砂系の例一
}

安本善征 ${ }^{1} \cdot$ 宇多高明 $^{2} \cdot$ 松原雄平 $^{3}$

\begin{abstract}
近年急激に侵食が進む鳥取砂丘前面の海浜について, 現地踏査, 空中写真および深浅測量データにより海浜地形の長期的 変化と土砂の偏在による土砂問題を明らかにした。また粒径分級を考虑した汀線変化モデルにより，鳥取港の防波堤による 波の遮蔽効果に伴って鳥取砂丘前面から千代川河口へ向かう沿岸漂砂が起こることを明らかにした. 鳥取砂丘への侵食の波 及を防止するために，浚渫土砂の沖捨てや埋立てを禁止し，鳥取砂丘前面に投入するサンドバイパス・リサイクルを実施す る土砂管理計面を策定した.
\end{abstract}

\section{1.はじめに}

鳥取県は総延長約 $129 \mathrm{~km}$ の海岸線を有し，うち約 60 \%が砂浜海岸であるが，ほとんどの海岸で侵食が深刻化 している.一方，砂の異常堆積により港湾・漁港では航 路や泊地の埋没が起こり, 河口ではその閉塞がしばしば 問題となっている．海岸侵食と異常堆積による各施設の 機能障害（以下，「土砂問題」と呼ぶ）は表裏一体の関 係にありながら，これまで各々の管理領域で個別に対策 が行われてきた.

こうした状況下で, 鳥取県では港湾・漁港の航路や泊 地の埋没, 河口閉塞, 海岸侵食など, 砂に係わる問題を 山地から海岸までの流砂系一貫の立場から，各管理者お よび利用者が連携しながら解決していくための「鳥取沿 岸の総合的な土砂管理ガイドライン」を 2005 年 6 月に 策定し, 図-1に示す千代川, 天神川, 日野川流砂系と, ポケットビーチの浦富海岸, 気高海岸, 青谷海岸を対象 に土砂管理計画を策定した.

本論文では，わが国を代表する鳥取砂丘を有する千代 川右岸流砂系を対象として, まず海岸侵食の実態を空中 写真に基づく長期的汀線変化や深浅デー夕，さらには現 地・斜め空中写真撮影などにより明らかにする。その上 で予測モデルを構築し, 侵食問題を根本的意味から解決 し，鳥取砂丘を維持していくために、本ガイドラインを もとに策定した千代川流砂系の土砂管理計画を示す.

\section{2. 千代川右岸流砂系を例とした土砂問題の現状}

\section{（1）空中写真による長期的な汀線変化の解析}

土砂問題を解決していくためは, 各管理者, 利用者お よび県民がこれまでに起きてきている土砂問題を理解し, 問題を共有化する必要がある。このためまず 1947〜

\footnotetext{
1 鳥取県総務部財政課(前 県土整備部河川課)

2 正会員 工博 (財) 土木研究センター理事 なぎさ総合研究室長

3 正会員 工博 鳥取大学教授 工学部土木工学科
}

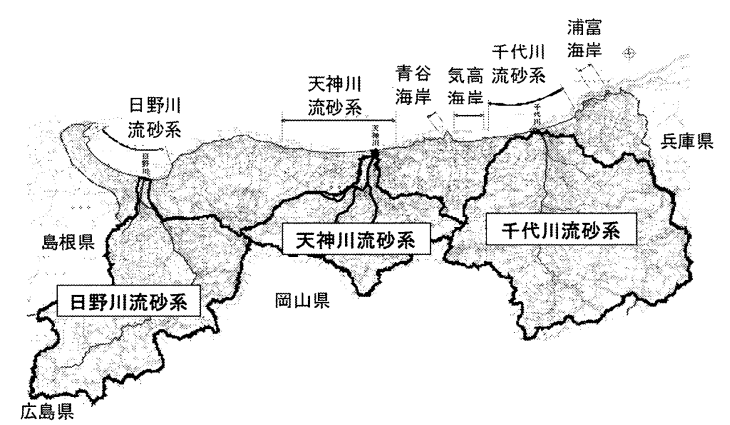

図-1 検討対象海岸（鳥取県全域図）: 千代川, 天神川, 日野川流砂系および浦富, 気高, 青谷海岸

2003 年に撮影された 9 時期の空中写真をもとに, 過去 56 年間の海岸線の長期的変遷を調べることにした。代 表的な空中写真として 2003 年の空中写真を図-2 に示す. 西端には鳥取港の防波堤が延び，それに隣接して千代川 が流入している．海岸の中央部以西には鳥取砂丘がある が, 中央より東側では保安林（松林）が海岸線近傍まで 迫っている，一方，東端には岩戸漁港の防波堤があり， その背後では防波堤による波の遮蔽効果により三角形状 の海浜が形成されている．またその一番奥には塩見川が 流入している. 塩見川の河口は, 岩戸漁港の航路の出口 に当たることから, 漁港への堆砂が問題になるパターン である.千代川河口部においても東端と同様に, 鳥取港 の防波堤による波の遮蔽効果により堆積域が形成され遮 蔽域外では侵食が考えられるが, この空中写真のみでは それを十分に判読することができない.

そこで, 防波堤による波の遮蔽域形成に伴う汀線変化 を定量化するため, 自然状態の砂浜が形成されていたと 考えられる 1947 年の空中写真から読み取った汀線を基 準として 2003 年までの汀線変化を求めた. 図-3 は当区 域に扔ける 1947〜2003 年の汀線変化である. 千代川河 口東側直近では汀線が最大約 $80 \mathrm{~m}$ 前進する一方, 鳥取 砂丘前面を中心として広い区域で汀線が後退している. また, 東端の岩戸漁港および塩見川の西側隣接部では汀 


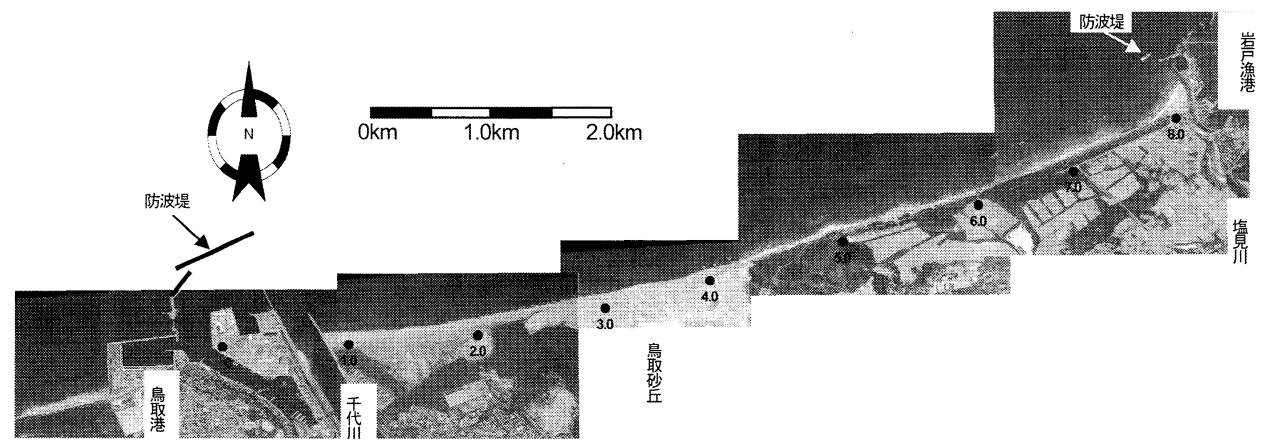

図-2 千代川右岸側海岸の空中写真（2003年撮影）

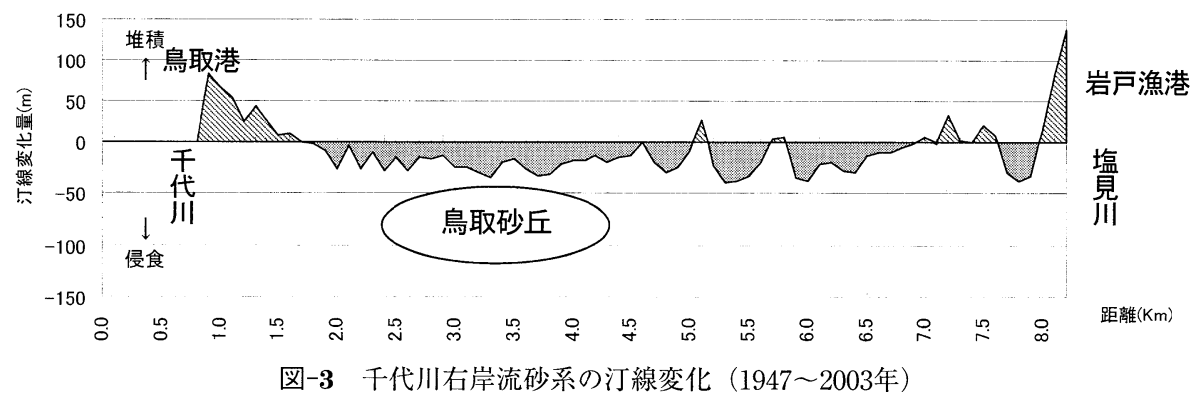

線が最大で約 $130 \mathrm{~m}$, 三角形状の前浜を形成しながら前 進した。なお，図-3の $5.0 \mathrm{~km}, 5.7 \mathrm{~km}, 7.2 \mathrm{~km}$ 付近 の三角形状の汀線の前進は 1997 年から現在までに建設 された人工リーフによる堆砂効果が現れたことによる.

以上より，千代川右岸流砂系では主として防波堤によ る波の遮蔽効果による二つの土砂問題が浮き彫りとなる。 第 1 は, 西端の鳥取港と千代川河口および東端の岩戸漁 港と塩見川河口での堆砂による航路・泊地の埋没, およ び河口閉塞であり, 第 2 は侵食により鳥取県のみならず わが国の貴重な自然財産の一つで，わが国最大の規模を 有する鳥取砂丘が失われていくことである.

\section{(2) 斜め空中写真による海浜変形調查}

2005 年 4 月 22 日, ヘリコプターによる鳥取海岸の斜 め空中写真撮影を行った.

a ) 千代川河口〜塩見川河口(千代川右岸流砂系全景) 写真-1 は鳥取港とそれに隣接する千代川河口から東 向きに約 $8 \mathrm{~km}$ の千代川右岸流砂系の全景である. 写真 中央に白く見えるのが鳥取砂丘である。砂丘は海岸線か ら陸側へと最大約 $2 \mathrm{~km}$ 発達している. 鳥取砂丘から手 前 (西) 側, 千代川河口までの間には幅約 $90 \mathrm{~m}$ の海浜 が延びている．これに対し鳥取砂丘の東側での海浜幅は 非常に狭く見える。また, 千代川の右岸導流堤位置から 東側に汀線が凹状となっている場所がほほ規則的に並び， 少なくとも矢印で示す 5 箇所でそれを確認できる. 逆に 汀線が周辺より突出している場所では, 沖合の白濁した 砕波が顕著に見え, そこが相対的に浅くなり, 典型的な
沿岸砂州の発達が確認できる。

b ) 鳥取砂丘

鳥取砂丘全体を海側から撮影したのが写真-2である. 海岸線に注目すると, 鳥取砂丘の東側では前浜がほとん ど消失し, 浜崖が形成されていることから侵食が進んで いることが見てとれる．しかも前浜が消失し，浜崖が形 成されている場所では汀線が凹状となるとともに，沖合

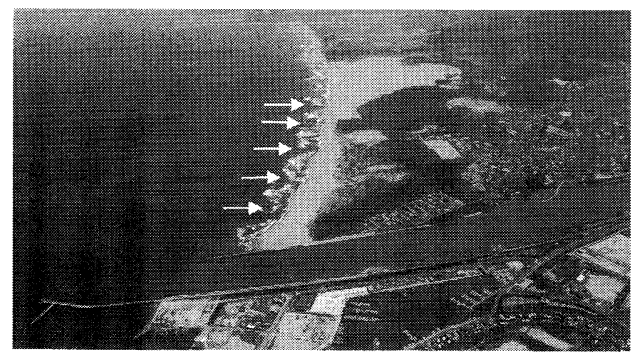

写真-1 鳥取港上空から撮影した鳥取砂丘方面の斜め空中写真

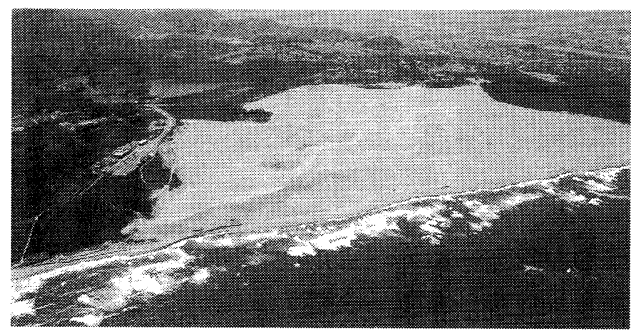

写真-2 鳥取砂丘の斜め空中写真 
に砕波が見えないことから深みが存在している，すなわ ち浜崖は局所的問題として形成されたのではなく，沖合 での海浜変形と密接な関係を有している.

c ) 岩戸漁港㧍よび塭見川河口周辺

写真-3 は千代川右岸流砂系東端の岩戸漁港から西向 きに海岸線を撮影したものである．岩戸漁港の防波堤に よる波の遮蔽域形成に伴って防波堤の付け根に向かって 三角形状の海浜が形成されている．塩見川東側は岬とな っており供給される土砂はなく、堆積土砂の大部分は防 波堤による波の遮蔽域の形成とともに西側海浜から運び 込まれものであり, 局所的で著しい堆積はそこから離れ た場所での侵食とセットになって起きている．とくに写 真中央部に白濁した状況からよく分かるように，4基の 人エリーフの東端で汀線の後退が著しく, 結果として護 岸のかなり長い延長が直接波に曝されるようになったと 推定できる．護岸の沖合ではほとんど砕波の白濁が見ら れないことから, 護岸の沖合も含めて深掘れが進んでい ることが明らかである，反対に岩戸漁港に隣接して流入 する塩見川河口では，河口部が白っぽく見えることから 砂が堆積していることが見てとれる.防波堤により回折 し，その後砕波して到達した波高の低い波が塩見川河口 に到達している。このことから塩見川河口部では非常に 浅くなっていることがわかり、塩見川河口においては隣 接する西側の海岸しか土砂供給源がなく、堆積した土砂 のほとんどはそこから運び达まれたものと推定される.

\section{(3) 現地踏查}

2005 年 4 月 8 日に千代川右岸流砂系の海岸踏査を行 い, 海岸侵食の実態を示す浜崖の形成を確認した.

写真-4 は鳥取砂丘馬の背前面の位置の西側で浜崖が 鳥取砂丘の本体を切り込んでいる状況を東向きに撮影し たもので，この付近で侵食が進んでいることをよく表し ている.

現地踏査によれば，鳥取砂丘東部の海岸では，砂丘地 の下部が侵食され, 浜崖が形成された後, 一部には砂が 急斜面を滑り落ちて安息勾配斜面となっていたが，その 上部には植生の根が露出している状況となっていた。一 般に植生が根を露出させて根付くことはなく,侵食の激 しさが伺える.また, 浜崖の露頭には多数の層状模様が 見られ, 海からの風により砂が長年吹き上げられ形成し た天然砂丘において自然状態で起こりえない侵食が進行 していることが明らかである.

写真-5 は 2006 年 3 月 17 日に撮影した鳥取砂丘の馬 の背前面にできた浜崖である. 浜崖の高さは約 $7 \mathrm{~m}$ あ り, 浜崖の上に立つ観光客は海へ近寄ることができない. 数万年のスケールで形成された鳥取砂丘が，人間の営み の影響によって歴史的スケールでみれば数十年というご く短い時間で失われたことになる，このことから、貴重

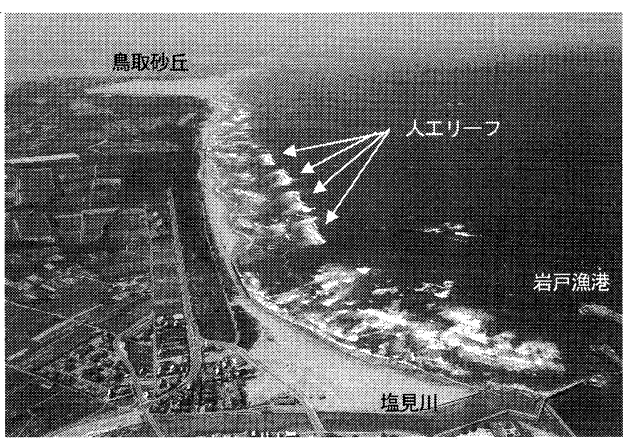

写真-3 岩戸漁港 - 塩見川河口, 鳥取砂丘の斜め空中写真

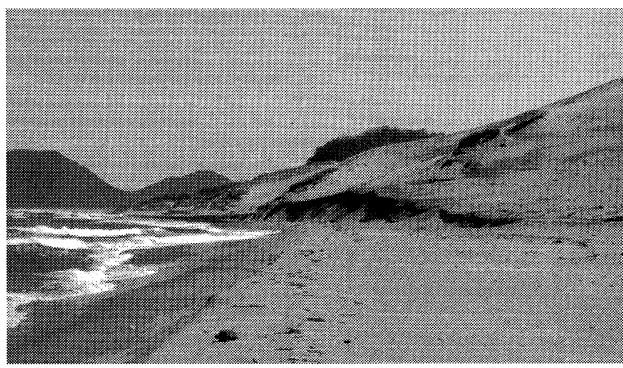

写真-4 鳥取砂丘前面の浜崖形成状況 (2005 年 4 月撮影)

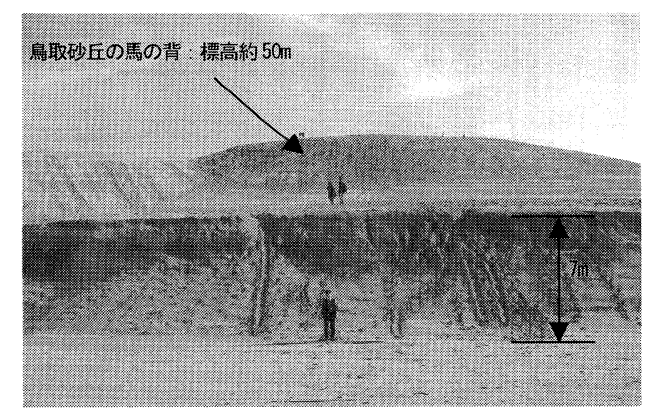

写真-5 鳥取砂丘前面の浜崖形成状況 (2006 年 3 月撮影)

な財産である鳥取砂丘を早急に元の自然な状態に戻す努 力が必要とされる.

\section{（4）深浅測量資料による海浜地形変化解析}

鳥取砂丘の海岸侵食の実態を明らかにするため, 千代 川右岸流砂系の海浜部で実施した深浅測量資料により鳥 取港が建設された 1987 年以降の海浜地形変化を解析し た。図-4 は 1987 年 8 月と 2003 年 9 月に実施した深浅 測量の結果を重称合わせ，堆積領域と侵食領域を示した ものである. 水深 $6 \mathrm{~m}$ 以浅ではバー・トラフが発達し, 深浅測量を実汀線 (水深 $0 \mathrm{~m}$ ), 水深 $6 \mathrm{~m}$ および水深 10 $\mathrm{m}$ の等深線に着目し堆積域と侵食域を示した。千代川 から $2.0 \mathrm{~km}$ 付近までの汀線および水深 $6 \mathrm{~m}$ の等深線は 前進し堆積域がみられる.また, 水深 $10 \mathrm{~m}$ の等深線も $1.5 \mathrm{~km}$ 付近まで前進し堆積域がみられる. 一方 $2.0 \mathrm{~km}$ 付近から東側では細長い侵食域がみられる。 


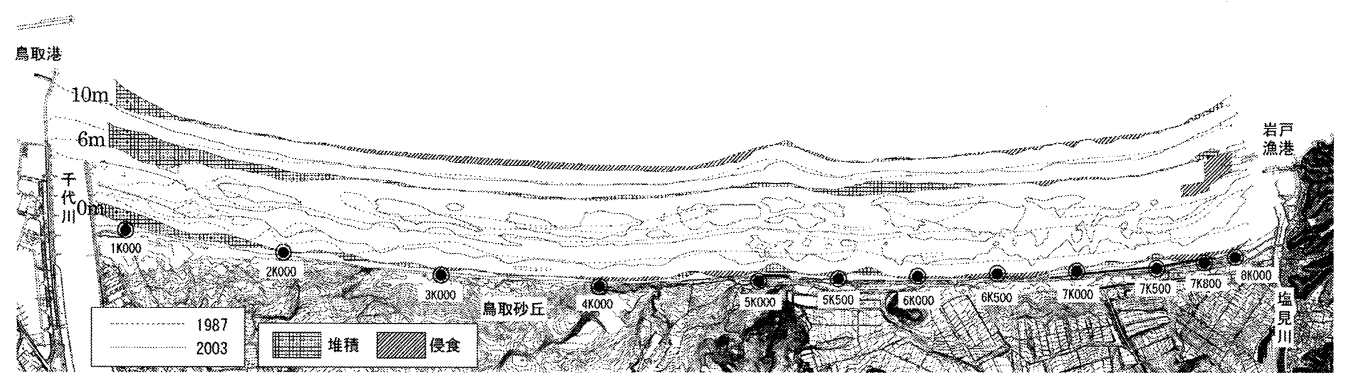

図-4 1987年と2003年の深浅図の重ね合わせ

\section{（5）海岸における主な侵食要因の推定}

宇多(2004)の示した 7 つ侵食要因をもとに, 空中写 真の解析, 斜め空中写真の判読および深浅測量による海 浜地形解析によれば，千代川右岸流砂系の主な侵食要因 は,

(1) 鳥取港防波堤等の建設による波の遮蔽域形成

(2) 岩戸漁港防波堤等の建設による波の遮蔽域形成

(3) 港湾 - 漁港の航路浚渫と土砂の沖捨てや埋立利用 と推定できる. すなわち, 当海岸では上記要因により長 期的に土砂収支のバランスが崩れ，海岸の土砂量が大き く減少するとともに人工構造物の影響で土砂が局所的に 偏在化することになったと考えられる. とくに千代川右 岸流砂系西端の鳥取港側と, 東端の岩戸漁港側への土砂 移動によって, 鳥取砂丘を含む海岸中央部では侵食が顕 在化したと考えられる. 千代川からの供給土砂が, 鳥取 港防波堤等の建設によって海岸にほとんど供給されない 状況下での侵食対策としては，鳥取港や岩戸漁港などの 社会基盤を撤去することは極めて困難であり, 反対に単 に人工構造物を造れば済むわけではなく，したがって海 浜土砂量を補うという策（養浜）が次善の策となる.

\section{3. 土砂動態モデルによる土砂問題の要因の解明}

\section{（1）土砂動態モデルの概要}

土砂供給源となる千代川と千代川左右岸（西側は白鬼 海岸から東側の岩戸漁港まで）の一連の流砂系を対象に 土砂動態モデルを構築した．河川流域の土砂生産性が高 いと考えられる千代川流砂系については，河川からの供 給土砂量の推定に 1 次元河床変動計算モデルを用いた. 河口部での計算結果（土砂量・粒径）を入力条件として, 海岸部に熊田ら (2002a，2002b)の研究によって開発さ れた粒径分級を考慮した汀線変化予測モデルを用いた。

（2）土砂収支の变遷と土砂問題の要因の定量化

同定した土砂動態モデルによって千代川流砂系の海浜 部における沿岸漂砂方向と沿岸漂砂量および土砂収支を 再現し, 土砂問題の要因を定量的に評価した.

図-5 は自然状態の海岸部の土砂収支を示す，その当 時は，千代川流域にダムはなく，海岸部でも防波堤等の
人工構造物は設置されていない. 1 次元河床変動計算モ デルの計算結果より千代川から海浜地形の形成に寄与す る粒径 $0.15 \mathrm{~mm}$ 以上の土砂が $8.0 \times 10^{4} \mathrm{~m}^{3} / \mathrm{yr}$ 流出し, 汀線変化予測モデルの計算結果より千代川河口から左右 岸へそれぞれ $3.4 \times 10^{4} \mathrm{~m}^{3} / \mathrm{yr}$ の土砂が供給され，堆積性 の自然状態の砂浜が形成されていた状況を再現した.

次に, 自然状態を初期条件として，千代川の河口付け 替えと鳥取港の建設, 岩戸漁港の建設, 突堤や人工リー フの設置, 港内の浚渫土砂の沖捨てや埋立て, 千代川で のダム建設や砂利採取の影響による供給土砂量の減少を 加味しつつ現在までの土砂収支の変遷を再現した。図-6 は 2003 年現在の土砂収支図である.

千代川右岸側に着目すると自然状態での沿岸漂砂方向 は東向きであった。しかし，現在では鳥取砂丘より西側 の沿岸漂砂の方向は, 自然状態とは逆向きの千代川（鳥 取港) 一向かう方向へ転じた。一方，鳥取砂丘より東側 の沿岸漂砂方向は，自然状態と変わらない東向きである. この結果, 鳥取砂丘前面は $1.4 \times 10^{4} \mathrm{~m}^{3} / \mathrm{yr}$ の割合で土砂 が失われている。

自然状態とは逆向きの沿岸漂砂が生じたことは，空中 写真や深浅測量による解析より明らかとなった鳥取港の 防波堤による波の遮蔽域内での堆積と遮蔽域外の侵食要 因を説明しており，防波堤による波の遮蔽域外から遮蔽 域内へ土砂が移動する漂砂メカニズムを再現している.

鳥取港および千代川河口における堆積と鳥取砂丘の侵 食による土砂問題が，鳥取港の防波堤建設に伴う波の遮 蔽域形成に起因することをこの土砂動態モデルによって 明らかにすることができたが，鳥取港に堆積した土砂は， 本来鳥取砂丘を形成していた貴重な砂である，過去に， 鳥取港の機能を維持するため, 堆積土砂のうち $2.0 \times 10^{4}$ $\mathrm{m}^{3} / \mathrm{yr}$ は，鳥取砂丘の形成に寄与することがない波に 上る地形変化の限界水深 $h_{c}$ (約 $10 \mathrm{~m}$ ) 上り沖へ投棄 - 埋 立て利用されてきた．このことが，鳥取砂丘前面の海岸 侵食にさらに拍車をかけた。

\section{4. 結 論}

本論文では，わが国を代表する砂浜の一つである鳥取 


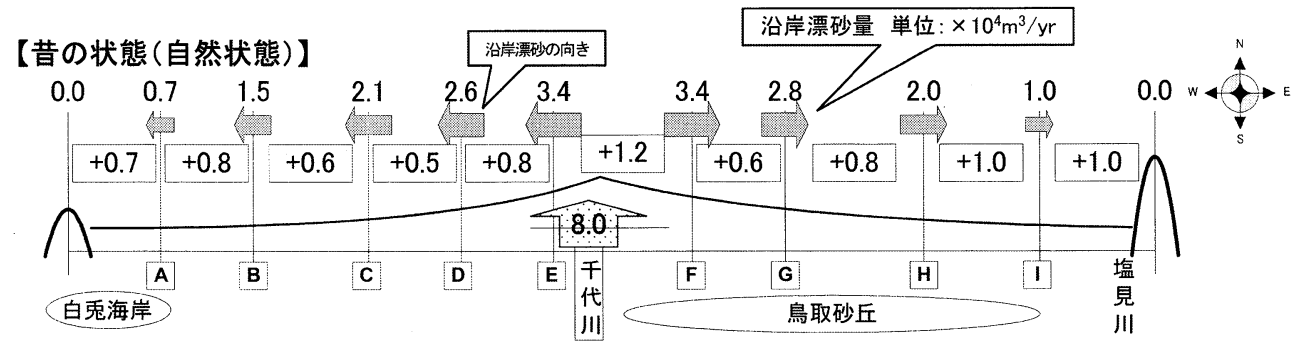

図-5 1947年当時の自然状態の土砂収支

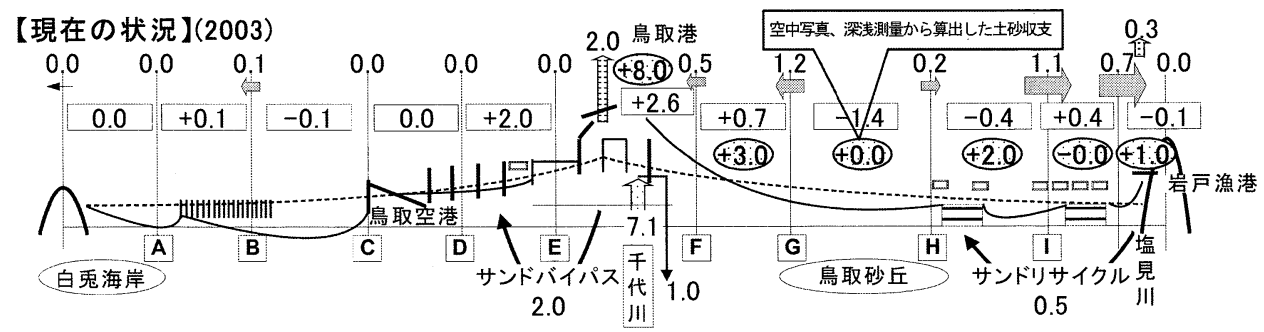

図-6 2003年時点の土砂収支

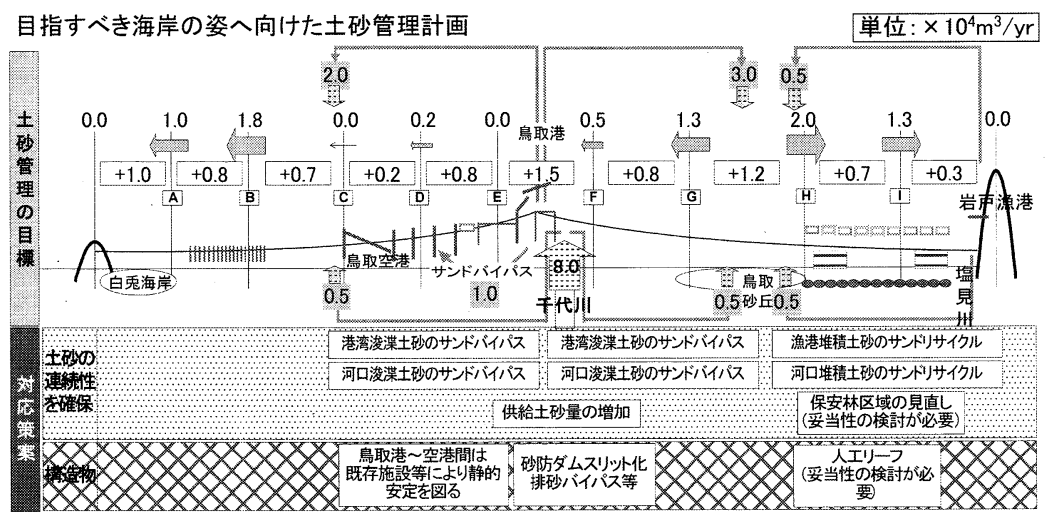

図-7 千代川流砂系の土砂管理計画

砂丘を有する千代川右岸流砂系を対象に，現地踏査，空 中写真および深浅測量データにより海岸地形の長期的な 変動と土砂の偏在化による土砂問題を明らかにした。そ して，河川・海岸一体となった粒径分級を考慮した土砂 動態モデルにより千代川流砂系全体の土砂収支と漂砂メ カニズムを再現することによって，流砂系の土砂問題の 要因を定量的に評価した.

鳥取港の防波堤による波の遮蔽効果により鳥取砂丘前 面から千代川へ向かう沿岸漂砂が起こることを明らかに したが，この漂砂の向きは自然状態の向きとは逆であり， 本来鳥取砂丘前面にあるべき土砂が浚渫によって漂砂の 系外へ運ばれ失われている状況が明らかになった。

以上より，鳥取砂丘への侵食の波及を防ぐために，第 1 章に示した「鳥取沿岸の総合的な土砂管理ガイドライ ン」をもとに、浚渫土砂の沖捨てや埋立てを禁止し，鳥 取砂丘前面に投入するサンドバイパス・リサイクルを実
施する千代川流砂系の目指すべき海岸の姿に向けた土砂 管理計画を図-7のように策定した(安本ら，2006).

謝辞：本研究を実施するにあたり，（株）建設技術研究 所東京本社の原 文宏氏, 平野宜一氏に協力をいただい た.ここに記して謝意を表する。

\section{参 考 文 献}

宇多高明 (2004)：海岸侵食の実態と解決策，山海堂，p. 304. 熊田貴之 - 小林昭男 - 宇多高明 ·芹沢真澄 - 星上幸良 - 増田光一 (2002a)：混合粒径砂の分級過程を考慮した海浜変形モデルの 開発，海岸工学論文集，第 49 巻， pp. 476-480.

熊田貴之 - 小林昭男 - 宇多高明 - 芹沢真澄 - 三波俊郎 - 増田光一 (2002b) : 河口デルタの汀線・粒径変化の予測モデルー沿岸漂 砂による分級作用の再現 -, 海岸工学論文集, 第 49 巻, pp. 481-485.

安本善征・宇多高明・松原雄平 ・佐藤慎司 (2006)：鳥取沿岸の総 合的な土砂管理ガイドラインの策定と実施, 海洋開発論文集, 第 22 巻, pp. $415-420$ 